\title{
Enterprise Risk Management, Top Management Demographics, Macro Environment and Organizational Performance: Evidence from Kenyan State-Owned Corporations
}

\author{
Emma Otieno \\ Doctoral Candidate \\ School of Business \\ University of Nairobi, Kenya \\ Professor Martin Ogutu \\ Professor \\ School of Business \\ University of Nairobi, Kenya \\ Professor BitangeNdemo \\ Professor \\ School of Business \\ University of Nairobi, Kenya \\ Professor Ganesh Pokhariyal \\ Professor \\ School of Mathematics \\ University of Nairobi, Kenya
}

\begin{abstract}
This journal is a conceptualization of the relationship between Enterprise risk management, Top management demographics, Macro environment and performance. Some researchers have argued that Enterprise risk management influence performance positively whereas others have advanced that the influence is negative whereas others have contended that this strategic management practice is fairly recent, adopted to varying extent and its influence on performance is yet to be fully realized. There is also no agreement on the moderating influence of Top management demographics on the relationship between Enterprise risk management and organizational performance. The moderating influence of Macro environment on the relationship between Enterprise risk management and performance is also not conclusive. It was for this reason that there was need to explore the existence of these relationships. The context of the study was Kenyan State-owned corporations.
\end{abstract}

Keywords: Enterprise risk management (ERM), Top management demographics (TMD), Macro-environment and Performance

\section{Background}

The approaches to risk management have evolved to meet the growing requirement of effectiveness in organizations (Verlag, 2014). Firms have in the recent past commenced the adoption of more comprehensive approach known as ERM. However, this seems to be less in non-financial institutions (McShane et al., 2011). Managing risks has become a critical function for top management in the increasingly turbulent environment. Traditionally, firms have been practicing silo-based risk management strategies that only focus on certain aspects of the wider corporate risk management framework (Ulrich \& Wiersema, 1987). The upper echelon perspective advanced the relationship between TMT demographic characteristics, strategic decision such as consideration of strategic risk management and performance (McWhorter, et.al, 2006).

Hambrick and Mason (1984) ignited the debate in strategic management literature on the central part that TMTs play in devolving strategies that will align organizations with the environment and consequently influence performance. The argument is that TMD such as age, education, tenure, gender and functional background, which reflects the underlying cognitive, and affective managerial characteristics, predict the capability to adopt risk management and hence influence performance. Organizations both respond to and operate upon the context in which they are embedded. Top management teams are critical in understanding these contexts and creating the fit between the organization and the environment. 
According to Culp (2002), it is therefore critical to explore ways in which non-financial companies can implement ERM. The primary task of top management is to develop strategies that enhance the relationship between the organization and its macro environment (Pearce \& Robinson, 2003). Top Management must therefore keep reexamining the macro environment to develop systems such as risk management to support already identified strategies for the organization's survival (Miller et al., 1998).

Top management mental models influence the decision to adopt ERM (Nielson \& Nielson, 2013). The role of the organization's TMDs in influencing strategic response such as adoption of ERM, to the happenings in this environment to enhance the achievement of organizational objectives can be further researched to establish its influence (Schendel \& Hofer, 1979). This journal reviews the following theories pertinent to ERM, macro-environment, top management demographics and performance. These include; Contingency theory of ERM (Kaplan \& Mike, 2014); Upper Echelon theory, (Hambrick \& Mason, 1984), Open Systems theory (Ansoff \& McDonnell, 1990) and Stakeholders theory, (Freeman, 1984).

\section{Literature Review}

ERM dimension was conceptualized as the independent variable to include indicators such as: context setting; risk assessment; risk evaluation and communication. Top management demographics was conceptualized as a moderating variable with indicators including: age, education, functional background, gender and tenure in organization. Macroenvironment was conceptualized as moderating variable and considered indicators included: political, economic, social, technological, legal and ecological factors. Finally, performance was conceptualized as the dependent variable with two major indicators namely: financial and non-financial organizational performance.

This study was anchored on the following theories pertinent to ERM, macro-environment, top management demographics and performance. These include; Contingency theory of ERM (Kaplan \& Mike, 2014); Upper Echelon theory, (Hambrick \& Mason, 1984), Open systems theory (Ansoff \& McDonnell, 1990) and Stakeholders theory, (Freeman, 1984).

\section{Contingency Theory of Enterprise Risk Management}

Kaplan and Mike (2014) advanced Contingency theory of ERM, which posits that strategic risk management practice may be more effective through matching ERM with the inherent nature of the organizational types of risks experienced. The essence of a contingency theory of ERM would be, to find a 'fit' between contingent factors and firms' ERM practices and establish propositions of fit that will result in desired outcomes (Hammond et al., 2006). The theory concludes that to effectively manage risks, it depends on contingent of organizations' circumstances and context (Kaplan \& Mike, 2014). In this study, contingency theory of ERM guided the conceptualization of ERM, which is one of the key strategic management practices, adopted by the organizations to influence performance of Kenyan StateOwned Corporations. Contingency theory of ERM has however been criticized on the basis that it ignores the endogeneity factors of organizations (McShane et al., 2011). The theory assumes a constant positive association between ERM and performance even in cases where the influence may not be singly attributed to ERM (Beasley et al., 2006). Seemingly, the theory still requires empirical data especially in different context of ERM such as State-Owned corporations. Additionally, the combination of ERM with other variables such as Macro environment and Top management demographics was necessary to strengthen this theory.

\section{Open Systems Theory}

According to Burnes (2004), Open systems theory refers to the concept that the environment influences organizations because they depend and serve in the context of the environmental occurrences. This is premised on the postulation of Ansoff and McDonell (1990) that organizations are environment serving and dependent. The environment consists of forces that are economic, political, technological or social in nature (Wernerfelt, 1984). External factors are outside the physical confines of an organization and firms do not have control over them. These factors cause turbulence and uncertainty but also provide resources that sustain the organization to survival, thereby requiring organizations to consider strategic risk management as a means to mitigate the impact of environmental uncertainties while exploring available resources for survival (Carpenter et al, 2004). This means that as top managers develop strategies; they will be subject to macro-environment influences and will need to continuously ensure that strategic decisions take cognizance of risks being span by its environment (Ansoff \& McDonnell, 1990). This theory guided the conceptualization of macro-environment influence on performance in this study. Proponents of Open systems theory share the perspective that an organization's survival is dependent upon its relationship with the environment (Wernerfelt, 1984). However, this theory has been criticized for its lack of adopting an integrated, interactional approach using multiple resource dependence strategies thus little is known about interaction of different strategic management practices such as strategic risk management. 
This creates the need to explore multiple resource dependency and strategy relationships (Kim \& Lim, 1988). Top managers develop various strategies to cope with risks span by the macro-environment influences. The risk management strategies are perceived and enacted differently leading to variations in performance of organizations.

\section{Upper Echelons' Theory}

Upper echelons' theory as postulated by Hambrick and Mason (1984) argues in the context of how top management acts as a reflection of the firm through playing an important and instrumental role towards the overall firm performance. Further, the theory goes ahead to reveal that managers' characteristics' influence the decisions' that they make towards the firm and thus the strategic management practices and actions to be adopted by the organizations to realize key goals (Henderson, Miller \& Hambrick 2006). According to this theory, TMT demographics include functional background, education, and age. Researchers have also included tenure (Nielson \& Nielson, 2013) and others gender (Marimuthu \& Kolandaisamy, 2009) as comprising TMDs. In this study, upper echelons' theory sought to explain how top management demographics affect the adoption of ERM to influence organizational performance. The propositions by the upper echelon theory have brought forth significant literature in research of the role of TMTs and performance, thus suggesting that top managers personal characteristics influence outcomes such as performance (Zenger \& Lawrence, 1989). However, this theory has been criticized for its focus on 'teams' approach thus generating causal descriptions rather than causal explanations. Suggestion has been made to advance beyond TMTs to study demographics proxy (Carpenter et al., 2004).

\section{Stakeholder Theory}

Stakeholder theory advances that organizational performance is a function of how well an organization meets its goals to satisfy stakeholders. It further states that the interconnected networks of stakeholders affect the decision making process and in essence effectiveness and outcome of the firm (Freeman, 1984). Shareholders are an important constituent of stakeholders and profits are a critical output but not necessarily the main one, further whereas the actions of managers may serve the interest of shareholders, there are other important players whose interest must be taken care of too (Child, 1972). Organizational performance according to stakeholder's theory is viewed as the extent to which the organization satisfies the interest of its stakeholders (Radner \& Shepp, 1996). This theory has caused the evolution of performance measurement from the traditional focus on profits, which are returns on assets to include other nonfinancial and intangible measures such as customer-centric perspective and other internal processes (Kaplan and Norton, 1996). Measurement of performance has evolved over time from focusing on financial measures despite its continuing relevance to include Sustainable Balanced Score Card approach (Pfennigstorg, 1977) including contemporary, intangible and externally oriented measure (Kinuu, 2014). This study operationalized organizational performance along the result-based performance management approach, anchored on the Balanced Score Card approach.

\section{Methodology}

This study aimed at establishing the influence between Enterprise risk management, macro environment and Top management demographics and the performance of Kenyan state-owned corporations. To achieve this objective, primary data was collected from 92 state owned corporations. The classification of state corporations is based on broader clusters of research institutions and executive agencies, agencies of regulations, commercial agencies, agencies of strategic functions, education training both universities and territories (Taskforce on Parastatal Reforms, 2016). Out of the population of 187 state corporations, 34 are Agencies that are purely commercial, 21 are agencies that deal with strategic functions, 62 are agencies that are executive in nature, 25 are agencies that deal with regulations and 45 are institutions that undertake research, universities in public category and training and tertiary level.

This study was anchored on the positivist research philosophy, since it was about theory testing. Methodologically, the study adopted a cross-sectional research design and applied Proportionate Stratified random sampling. The estimated total sample size was arrived at using Yamane (1967:886) formulae. Data was collected using a structured questionnaire. Preliminary tests to determine viability were first carried out together with descriptive statistics. The descriptive statistics employed included the one sample $t$ test, means, standard deviation, frequencies and coefficient of variations. Inferential statistics such as factor analysis and Pearson's correlation were used. The study variables were then operationalized and tests used for diagnosing multiple regression.

Conceptual framework explains relationship among linked concepts and explains the connections between the variables under study (Ravitch \& Riggan, 2012). The conceptual framework for this study was developed based on the literature and empirical reviews. The relationship was conceptualized and schematized in a conceptual framework and shown below: 
Figure 2.1: Conceptual Framework

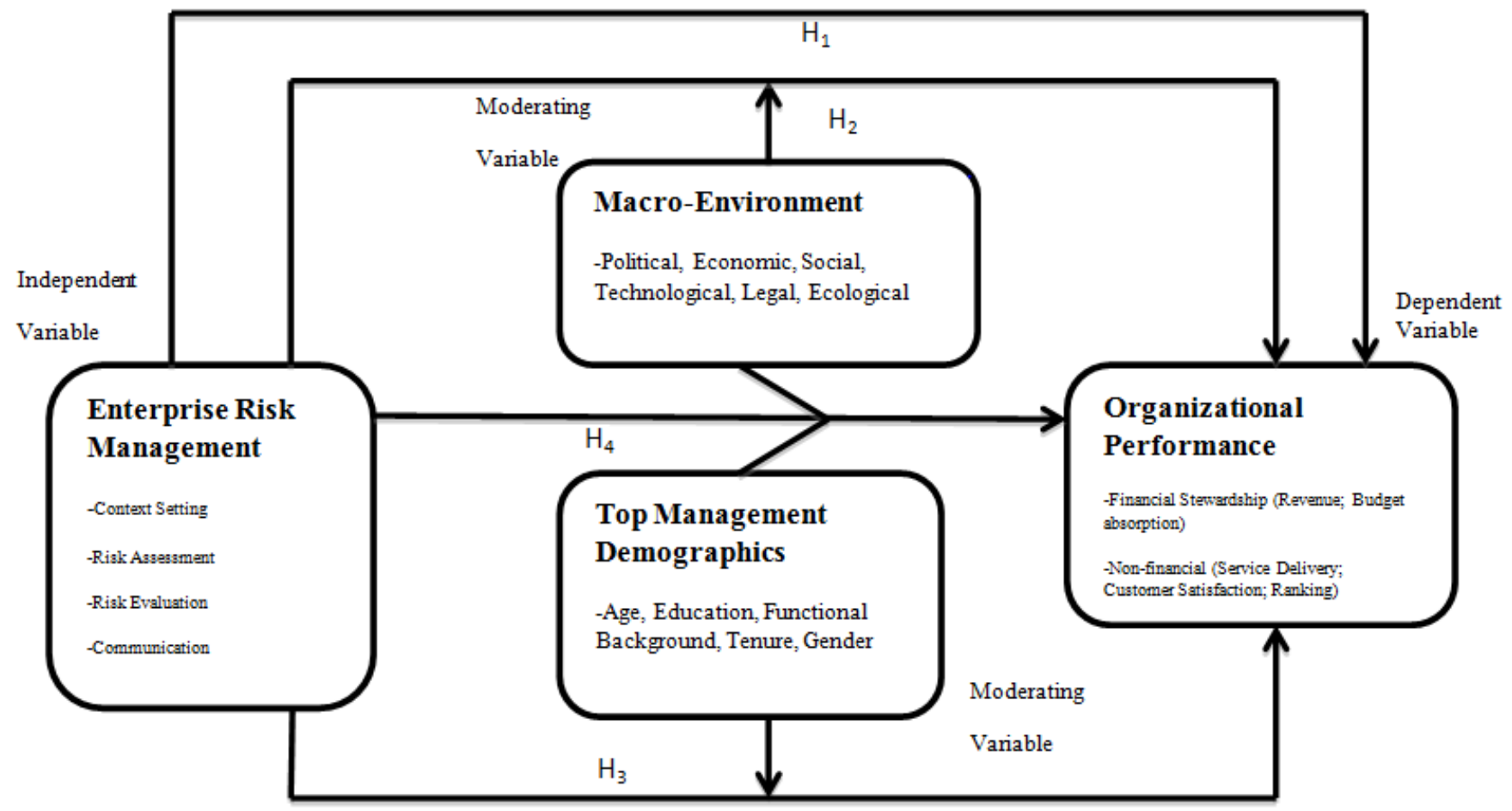

\section{Testing}

This study intended to determine the effect of Macro environment and top management demographics on the relationship between enterprise risk management and performance in Kenyan State-Owned corporations. To achieve this overall objective, four hypotheses were enumerated. Table 4.27 gives a summary of the objectives, corresponding hypotheses that guided the study, the results and conclusion on the hypotheses. Both linear and multiple regression analysis statistical tools were used to analyze the data.

Table 4.27: Summary of Hypotheses Conclusions

\begin{tabular}{|c|c|c|c|}
\hline Objective & Hypothesis & Results & Remarks \\
\hline $\begin{array}{l}\text { To establish the influence of enterprise } \\
\text { risk management on the performance of } \\
\text { Kenyan State Owned Corporations }\end{array}$ & $\begin{array}{l}\text { H}_{1} \text { : ERM has a significant effect } \\
\text { on performance in Kenyan State } \\
\text { Owned Corporations }\end{array}$ & $\begin{array}{l}\mathrm{R}^{2}=0.11 ; \quad \mathrm{F}=6.439, \quad \mathrm{P}- \\
\text { Value }=0.014<0.05 \\
\beta=0.753, \quad \mathrm{t}=2.538, \quad \mathrm{P}- \\
\text { Value }=0.014<0.05\end{array}$ & Supported \\
\hline $\begin{array}{l}\text { To establish the influence of macro } \\
\text { environment on the relationship } \\
\text { between enterprise risk management } \\
\text { and performance in Kenyan State } \\
\text { Owned Corporations }\end{array}$ & $\begin{array}{l}\mathbf{H}_{2}: \text { The relationship between } \\
\text { ERM and performance in Kenyan } \\
\text { State Owned Corporations is } \\
\text { significantly moderated by macro } \\
\text { environment }\end{array}$ & $\begin{array}{l}\mathrm{R}^{2}=0.109 \\
\mathrm{~F}=3.547, \quad \mathrm{P}-\text { Value }= \\
0.018<0.05 \\
\beta=-0.044, \mathrm{t}=-1.554, \mathrm{P}- \\
\text { Value }=0.124>0.05\end{array}$ & $\begin{array}{l}\text { Not } \\
\text { supported }\end{array}$ \\
\hline $\begin{array}{l}\text { To determine the effect of top } \\
\text { management demographics on the } \\
\text { relationship between enterprise risk } \\
\text { management and performance in } \\
\text { Kenyan State Owned corporations }\end{array}$ & $\begin{array}{l}\text { H}_{3}: \text { The relationship between } \\
\text { ERM and performance in Kenyan } \\
\text { State Owned Corporations is } \\
\text { significantly moderated by top } \\
\text { management demographics }\end{array}$ & $\begin{array}{l}\mathrm{R}^{2}=0.135 \\
\mathrm{~F}=3.885, \quad \mathrm{P}-\text { Value }= \\
0.043<0.05 \\
\beta=-0.833, \mathrm{t}=-5.993, \mathrm{P}- \\
\text { Value }=0.047<0.05\end{array}$ & Supported \\
\hline $\begin{array}{l}\text { To establish the joint effect of } \\
\text { enterprise risk management, top } \\
\text { management demographics and macro } \\
\text { environment on the performance in } \\
\text { Kenyan State Owned Corporations }\end{array}$ & $\begin{array}{l}\mathbf{H}_{4}: \text { The joint effect of ERM, TMD } \\
\text { and ME on the performance in } \\
\text { Kenyan State Owned Corporations } \\
\text { is different from their individual } \\
\text { effect }\end{array}$ & $\begin{array}{l}\mathrm{R}^{2}=0.404, \quad \mathrm{~F}=6.558, \quad \mathrm{P}- \\
\text { Value }=0.001<0.05\end{array}$ & Supported \\
\hline
\end{tabular}




\section{Findings}

The study was conceptualized along four main variables namely; Enterprise risk management, Macro environment, Top Management demographics and organizational performance. The variables were measured using 16 sub-variables. Macro environment and Top management demographics moderated the relationship between Enterprise risk management and organizational performance. Enterprise risk management as the study's independent variable was measured using 4 sub-variables consisting 27 items while Macro environment that played a moderating role was measured using 4 sub-variables consisting of 26 items. Top management demographics was measured using 5 subvariables made up of 7 items whereas organizational performance which was the dependent variable was measured using 2 sub-variable made up of 5 items.

The overall objective of this study was captured through four specific objectives and corresponding hypothesis. The first objective was achieve by setting the hypothesis that, Enterprise risk management has a significant effect on the performance of Kenyan owned state corporations. The Enterprise risk management components were then composited to test the effect of financial, non-financial and overall organizational performance. ERM explained $10.2 \%$ of the variation in financial performance, $7.2 \%$ in non-financial performance and $11 \%$ variation in organizational performance. The findings revealed that on the overall, Enterprise risk management had a positive influence on financial, non-financial and overall organizational performance. The study therefore supported the hypothesis that, Enterprise risk management has a significant effect on the performance of Kenyan owned state corporations.

The second objective of this study was captured by the hypothesis that, the relationship between Enterprise risk management and performance of Kenyan owned state corporations is significantly moderated by macro environment. This hypothesis was tested in three steps corresponding to the Baron and Kenny (1986) model for testing mediation. In the first step, ERM was demonstrated to have a significant effect on organizational performance. In the second step, it was established that ERM and Macro environment components when composited had a significant negative effect on organizational performance and it accounted for $8.4 \%$ variation of organizational performance. In the third step, upon the introduction of the interaction term, it was established that Macro environment did not moderate the relationship between Enterprise risk management and organizational performance. The study therefore did not support the hypothesis that the relationship between Enterprise risk management and performance of Kenyan owned state corporations is significantly moderated by macro environment.

The third objective was expressed through the hypothesis that the relationship between Enterprise risk management and performance of Kenyan owned state corporations is significantly moderated by Top management demographics. The influence of ERM on the performance of Kenya owned State Corporations was first tested. The study found that the influence of ERM on organizational financial, non-financial and overall performance was significant. The study further examined the moderating influence of Top Management on the relationship between ERM and organizational performance. Top Management was found to have a significant moderating effect on the relationship between ERM and overall organizational performance. Finally, the fourth objective of the study found that ERM, Macro environment and Top management demographics jointly had a significant effect on the overall organizational performance.

\section{Enterprise Risk Management and Organizational Performance}

The first objective of the study was to establish the influence of enterprise risk management on performance of Kenyan owned State Corporations. To establish the objective, the corresponding hypothesis tests were undertaken, to determine the percentage of variation in the financial, non-financial and overall organizational performance as accounted for by enterprise risk management. Scientific research in the field of strategic management advances that the adoption and implementation of proper strategic management practices such as enterprise risk management is critical for the achievement of organizational performance (Pfennigstorg, 1977).

To test this advancement, the study set the hypothesis, H1: ERM has a significant effect on performance of Kenyan State Owned Corporations. The first test therefore, sought to establish the influence of enterprise risk management on financial performance of Kenyan owned State Corporations. The research findings supported the hypothesis. It was established that enterprise risk management explained 10.2 percent of financial performance. The regression model was significant at $\mathrm{F}$ ratio $=6.845$ with a $\mathrm{p}$ - value of 0.011 . Since the calculated $\mathrm{p}$-value was less than 0.05 , this indicated that the model was robust enough to explain the relationship between the ERM and financial performance of Kenyan owned State Corporations. As a comprehensive strategic management practice, ERM, which agrees with the Contingency theory of ERM in advancing the importance of achieving set organizational goals, including profitability and financial goals, is a strategic management practice that manages organizational risks comprehensively. This finding relating to, ERM and financial performance of Kenyan owned State Corporations, was aligned to the finding by Yegon (2015) 
Who noted that despite ERM being a recent strategic management practice in financial organizations, ERM significantly influenced non-financial organizational performance. This could be attributed to the government of Kenya's decisions to make ERM a mandatory strategic management practice for all its state corporations in its efforts to reform the public sector (GoK, 2009). Efforts to adopt this strategic risk management practice have been enhanced in the wake to the government revamping its efforts to achieve its reform programme, where the assuming of responsible fiscal stances, prudent resource utilization and prioritization of resource allocations has been given prominence. This finding supports advancement of the Contingency theory of ERM which postulates that Enterprise risk management responds to organizational risks that affect the achievement of an organization's strategic and financial objectives.

The second test sought to determine the influence of enterprise risk management on non-financial performance of Kenyan owned State Corporations. The research findings supported this hypothesis. It was established that enterprise risk management explained 7.2 percent $(\mathrm{R} 2=.072)$ of non-financial performance. The regression model was significant at $\mathrm{F}$ ratio $=4.568$ with a $\mathrm{p}$ - value of 0.037 . Since the calculated $\mathrm{p}$-value was less than 0.05 , this indicated that the model was robust enough to explain the relationship between ERM and non-financial performance variables. These findings support the studies by PWC (2015) and Yegon (2015), which established that enterprise risk management influences non-financial performance in organization. The study further stated that ERM is now considered a breakthrough in strategic management practice, with a high adoption rate in non-financial sector and governments as businesses, albeit being at nascent stages of its adoption. This could be attributed to the fact that government agencies are gradually shifting from the long-standing unsustainable fragmented traditional response to risk approach. Traditionally, governments tended to operate under the doctrine of government immunity and therefore absorbed all their risks without devising any risk management strategies for the reason that, its agencies operated fully as carriers of public powers and duties. This understanding made government agencies immune, self-sufficient and difficult to be wipedout unlike the businesses in the private sector. It was at its realization of the dwindling economic performance over time, coupled with decline in productivity and less funding, which imposed an increased social and economic burden on the government, that government sought to enhance governance among its institutions to spur its macro-economic growth (GoK, 2013). According to the study by PWC (2012) the only aspects in government that were being somewhat safeguarded from risks, were sections related to public properties as these were governed by other financial laws. There was no special focus on other operational risks of government business. However, in the efforts to enforce the adoption of the economic recovery reforms in governments, Enterprise risk management practice is now gradually being integrated in a sustainable manner, in all aspects of government business decisions more-so in non-financial matters. This finding further agrees with the Contingency theory of ERM in its advancement that ERM holistically addresses the full spectrum of organizational risks thereby supporting the achievement of not only financial but also non-financial organizational objectives.

To establish the influence of enterprise risk management on overall organizational performance, the composite index of organizational performance comprising of financial and non-financial performance was computed. The results of analysis established that enterprise risk management explained 11 percent $(\mathrm{R} 2=0.11)$ of organizational performance. The regression model was significant at $F$ ration $=6.439$ with a $p$ - value of 0.014 . Since the calculated $p$-value was less than 0.05 , this indicated that the influence of enterprise risk management on organizational performance was statistically significant at 95 percent confidence interval. This position was aligned to that of Njoroge et al (2013), who established that ERM and organizational performance is positive and significant. The results further corroborated the postulation of the Contingency theory of ERM (Kaplan and Mike, 2014) on the importance of Enterprise risk management in influencing organizational performance. In this study, Enterprise risk management was conceptualized based on four ERM pillars; contest setting, risk assessment, risk evaluation and communication. It is likely, that though the conceptualization of Enterprise risk management in this study did cut across the facets of strategic risk management practice, unlike counterpart organizations in the financial sector, owing to the Kenyan government's move to make Enterprise risk management a mandatory practice for its state corporations, the organizations have only adopted Enterprise risk management as a recent strategic management practice and to varying extents. The research findings show that despite the notable consensus on the positive influence of Enterprise risk management on organizational performance, its adoption among the Kenyan state owned corporations, similar to other organizations in the nonfinancial sector is still at nascent stages but gradually being integrated into government business and seen as starting to realize a positive impact on performance.

The finding of this study is consistent with those of other similar studies but contradicts the findings of some studies. For instance, studies by Gilley et al., (2002), Yegon (2015), Abdel-Azim and Abdelmoniem (2015) as well as Williams (2005), found that although enterprise risk management is a recently adopted practice in non-financial organizations, it had a positive statistically significant influence on organizational performance. 
Conversely, other researchers including Aaker and Jacobson (1987) and Belanes and Hachana (2009), advanced that due to being at the nascent stages of adoption and at varying stages in various organizations, enterprise risk management is yet to significantly influencing performance. Additionally, others posited that due to the fragmented implementation of enterprise risk management it is difficult to measure its impact (Rao, 2007; McShane et al., 2011 and Beasley et al., 2006).

Despite Enterprise risk management being at its nascent stages of adoption and integration in all aspects of government business, this study provided further evidence from the Kenyan owned state corporations, acknowledging ERM's influence on organizational performance. This is evident from the move to have all government agencies adopt enterprise risk management institutionalized through the recent reforms, with a view to enhance the state agencies performance, while steadily eroding the former government doctrine of immunity and non-accountability (GoK, 2009). It is noted that enterprise risk management improves the organizations' abilities to achieve the established nonfinancial, financial and overall goals. The findings that ERM influences organizational performance therefore provided additional empirical evidence to buttress the Contingency theory or ERM.

\section{Enterprise risk management, Macro environment and Organizational performance}

The second objective of the study was to determine the moderating effect of macro environment on the relationship between enterprise risk management and organizational performance. The study set out a second hypothesis, H2:The relationship between ERM and performance of Kenyan State Owned Corporations is significantly moderated by macro environment. Macro environment components namely political, economic, social, technological, environmental and legal factors were tested for their effect on performance independently. Results of analysis established that macro environment did not have a significant moderating influence on the relationship between enterprise risk management and organizational performance.

Macro environment failed to significantly influence the relationship between enterprise risk management and organizational performance despite the overall model being statistically significant with a p- value of 0.021 . Enterprise risk management accounted for 6.5 percent of variation in organizational performance, upon introduction of macro environment, the two variables accounted for 8.4 percent of the variation in organizational performance. The change upon the introduction of the interaction showed that $\mathrm{R} 2$ only improved by 2.5 percent from $\mathrm{R} 2=0.084$ to $\mathrm{R} 2=0.109$. The overall model indicated that the interaction was statistically significant with a p-value of 0.018 , however, the Beta coefficient for interaction term was not significant with a p- value of 0.124. Since the calculated p-value for the interaction was greater than 0.05 , it implies that there was no significance change on the relationship between enterprise risk management and organization performance due to the effect of macro environment, as moderation takes effect if the interaction term is significant.

Tests were conducted on the six PESTEL macro-environment sub-variables as conceptualized by Pearce et al, (2012). The findings showed that on introduction of macro environment (political environment), despite the overall model being statistically significant, ERM and macro environment (political environment) did not significantly influence organization performance, neither did moderation take effect. Decisions of governments tend to be influenced by deepseated political convictions. The finding regarding the statistical insignificance of the political factor would be attributed to the timing factor, considering that the study was undertaken at a time, when the country had just concluded the general elections, during this period, the Kenyan government was witnessing political consensus and synergy building within its political system.

The findings additionally showed that on introduction of macro environment (economic environment), the model was statistically significant. However, further analysis of the interaction term indicated that the interaction of ERM and macro environment (economic environment) insignificantly influenced organization performance, thereby the conclusion that moderation did not take effect. This could be attributed to the fact that governments unlike private businesses are not governed by the principle of profit maximization, and while economy is an objective of responsible government, it is usually in most cases subordinate to other objectives inherent in the political and democratic structures of government. Technological factors are a key contributor to the dimensions that make up the external environment (Machuki \& Aosa, 2011). The study did analyze macro environment (technological environment). The overall model of macro environment (technological environment) was significant. However, further analysis of the interaction term indicated that the interaction of ERM and macro environment (technological environment) insignificantly influenced organization performance. The Beta coefficient for interaction term was not significant, thereby the conclusion that moderation did not take effect. This could be attributed to the slower pace in which government has gone about investing in technology, integrating technology in all its operations and facilitating culture change to foster acceptance of the same which has been perceived to be less effective and less efficient than the implementation in the private sector. 
Additionally, the belief that technology in itself automatically transforms organization performance has proved otherwise in the public service, requiring state agencies to constantly review and update their strategic interventions beyond automation in order to attain organizational performance.

Macro environment (social environment) was not significant. Further analysis of the interaction term indicated that, the interaction of ERM and macro environment (social environment) insignificantly influenced organization performance. The Beta coefficient for interaction term was not significant, thereby the conclusion that moderation did not take effect. Legal dimension of the external environment that is mainly characterized by the laws and regulations that affect the organization is considered a critical factor that must be given attention by the organization (Pearce et al, 2012). Macro environment (legal environment) was analyzed but despite the overall model being statistically significant, further analysis of the interaction term was not significant, thereby the conclusion that moderation did not take effect.

The results show that despite the overall models in all aspects of macro environment being statistically significant, political, economic, social, technological and legal factors were not statistically significant with regard to their influence on the relationship between enterprise risk management and organizational performance. The results of the analysis of the macro environment factors did not provide enough evidence to support the hypothesis that the relationship between ERM and performance of Kenyan owned state corporations is significantly moderated by macro environment. The results supported findings by Machuki and Aosa (2011), who found that external environment did not have statistical significance on organizational performance. However, the results contradict those of Murgor (2014) and Kosure (2015) who established that external environment influences organizational performance.

Among the five indicators of macro environment used in the study, economic, technological and legal factors were reported to have an effect on enterprise risk management, implying that they influence the adoption of strategic risk management practices adoption by the organization, whereas political and social factors were found not to significantly affect the adoption of enterprise risk management. The finding regarding the statistical insignificant of the political factor, with the existence of statistical significant of economic factor on enterprise risk management in Kenyan owned state corporations, contradicted the findings of other researchers including findings by Njoroge (2015) who also established that environment influences organizational performance and that there exists a relationship between the external environment and organizational performance.

Inclusion of the moderating variable Macro environment brought new insights to the relationship between Enterprise risk management and organizational performance. The study showed that, Macro environment did not significantly moderate the relationship between Enterprise risk management and the performance of Kenyan owned state corporations. It was established from the findings, that while it is considered conventionally and supported by Open systems theory (Burnes, 2004) that organizations are dependent on occurrences within the external environment and that Macro environment forces influences organizational strategic management practices including strategic risk management (Hammond et al., 2006), the study findings showed otherwise. From the analysis of respondent comments, it can be explained that despite the effort by government to introduce reforms among state corporations, part of which included the pronouncement of ERM as a compulsory strategic management practice, unlike their counterpart financial sector organizations whose critically scan their external operating environment, design appropriate risk management strategies and follow through implementation for their survival, Kenyan owned state corporations, have continued to rely on exchequer funding for sustainability on the one hand, whilst on the other, the accountability mechanisms have been considerably lower. Owing to this, the state corporations tend to be less stringent in the scanning of macro environment in the process of designing their organizational risk management strategies.

It is evident that there exist different levels of the effect of political, economic, social, technological and legal factors that characterize the operating environment of Kenyan owned state corporations (Njoroge, 2015), of which the reported variation of the relationship between enterprise risk management and organizational performance can somewhat be attributed to. The statistically not significant results of the influence of macro environment on the relationship between ERM and organizational performance notwithstanding, organizations cannot ignore the Macro-environment determined effect. However, the results could stand on their own merit because most studies have not directly tested enterprise risk management-macro environment-performance relationship.

\section{Enterprise Risk Management, Top Management Demographics and Organizational Performance}

The third objective of the study was to determine the moderating effect of top management demographics on the relationship between ERM and performance in Kenyan State Owned Corporations. The results of analysis showed that top management demographics had a moderating influence on the relationship between ERM and organizational performance 
To test this expectation the study set the hypothesis, H3: Top management demographics significantly influence the relationship between enterprise risk management and organizational performance. Enterprise risk management accounted for 11.2 percent of variation in organizational performance, upon introduction of top management demographics, the two variables accounted for 13.5 percent of the variation in organizational performance. The Beta coefficient of ERM and Top management were both significant with a p-value $=0.035$ and 0.049 respectively. Upon interaction R2 improved by 2.3 from 0.112 to 0.135 . The Beta coefficient for interaction term was significant with a pvalue of 0.049. Since the calculated p-value for the interaction was less than 0.05 , it implied that the moderation influence of top management demographics on the relationship between enterprise risk management and performance in Kenyan State-Owned Corporations was statistically significant.

The study proceeded to tests the five top management demographic sub-variables as conceptualized by (Nielson \& Nielson, 2013) and (Marimuthu \& Kolandaisamy, 2009). Upon analyzing interaction between ERM and age, R2 improved by 8.4 percent from 0.111 to 0.195 . Age had a statistically significant effect on financial performance but the effect on non-financial performance was statistically not significant. This finding was aligned to that by Mwangi (2018) who postulated that, the present of younger managers in Top management led to volatile performance. Overall, it was established that age had a moderating influence on the relationship between enterprise risk management and organizational performance. The findings are consistent with those of Child (1972) who found that older managers tend to be conservative and have lesser propensity to matters relating to risk management. It was observed that Kenyan owned state corporations, are mainly characterized by older top management teams.

Further analysis of enterprise risk management and functional background revealed that the two variables accounted for 11.9 percent of variation in organizational performance. The overall model was statistically significant. Functional background had no statistically significant effect on all the performance measures, implying that there was not enough evidence to support the moderation influence of top management demographics (functional background) on the relationship between enterprise risk management and organizational performance. Thus, skills and experience associated with functional background did not impact organizational performance. This finding contradicted that by Certo et al (2008) who established that functional background had a positive effect on performance. The difference in findings could be attributed to contextual differences.

Additionally, Enterprise risk management and education accounted for 11.9 percent of variation in organizational performance, with the overall model being statistically significant however, top management demographics (education) had no significant effect on all aspects of performance. This implied that there was not enough evidence to support the moderation influence of top management demographics (education) on the relationship between enterprise risk management and organizational performance. This finding was consistent with that of Mkalama (2014) who found that education had no statistically significant effect on performance. The finding was also consistent with those of Wiersema and Bantel (1992) who advanced that managers more often than not chosen from different streams based on their personalities, interest and cognitive abilities. This implied that the more Top management team are characterized by manager with different education levels and qualifications, the more performance declines.

Enterprise risk management and tenure accounted for 11.7 percent of variation in organizational performance, with the overall model being statistically significant. Tenure had a statistically significant effect on overall performance. However, its effect on financial and non-financial performance was statistically not significant. The findings relating to tenure and, financial and non-performance, were consistent with those of Hambrick and Mason (1984) who advanced that longer tenure by itself validates the correctness of previous decisions made by top manager who have served for long and have psychological investment in their respective organizations. This makes such managers averse to the adoption of emerging strategic management practices such as strategic risk management. Most top executives in Kenyan owned state corporations have served the government for a considerable length of time, some of them having served the same sector for their entire working life. This finding however, contradicts that by Certo et al (2008) who found positive relationship between tenure and financial performance. This could be attributed to contextual and methodological differences, since this study adopted a cross sectional survey design, while the study by Certo et al (2008) was a meta-analysis.

Gender had no statistically significant influence on all the measures of performance, implying that there was not enough evidence to support the moderation influence of top management demographics (gender) on the relationship between enterprise risk management and organizational performance. This was consistent with the findings of Mkalama (2014) and Mwangi (2018) who both established that gender did not affect performance in a statistically significant manner. The finding whoever contradicted that of Dezso and Ross (2012), who found that gender disparity in the Top management team improved firm's financial performance? This difference could be attributed to methodological and contextual differences. 
The study was carried out in USA public companies and adopted the longitudinal research design, whereas the current study adopted the cross-sectional design focusing on Kenyan owned state corporations.

The statistically significant results of the overall influence of top management demographics on the relationship between ERM and organizational performance are an indication that, organizations cannot overlook the established effect of top management demographics on strategic risk management and its influence of organizational performance. The study finding are in line with findings of some studies such as Aaker and Jacobson (1987) who in line with the advancement of the upper echelons' theory (Hambrick\& Mason, 1984), supported the view that top management teams are responsible to organizational decisions that influence the organizations' overall risk, therefore determine the organization's risk management strategy which influences performance. However, it contradicts other findings such as those by Arnaboldi and Lapsley (2014), who established that Top management had not significant influence on the relationship between strategic risk management and performance and further stated that, the varying influence could be attributed to the positioning of enterprise risk management in the organization, coupled with the lack of clarity on top management ownership of the risk management practice. The results are also not in tandem with findings by Belanes and Hachana (2009), who stated that, top management's influence on strategic risk management had a varying nonlinear relationship with organizational performance and those of PricewaterhouseCoopers (2004) which advanced that top management in the public sector were still viewing enterprise risk management as an external accountability device that does not impact on their operations and performance thus the variability in their involvement.

Top management demographics significantly moderated the relationship between Enterprise risk management and the performance of Kenyan owned state corporations. It was established from the findings that as it is advanced by the Upper echelons' theory (Hambrick \& Mason, 1984) that Top management demographics influences organizational strategic management practices including Enterprise risk management (MC Whorter et al., 2006) the study findings validated this proposition. It was however seen in the analysis of comments, that the despite the importance of Top management teams influence in the adoption of ERM, the gradual and rather slow pace of adoption of ERM can be attributed to the Top management team demographics. The enforcement of the adoption of Enterprise risk management by Top management and implementation of this practice in Kenyan owned state corporations, is currently being reinforced by more stringent checks, additional follow-through modalities and the requirement for more accountability on the actions of Top management as it relates to the adoption of ERM. Top management have the responsibility of developing and implementing organizational strategies to safe guard the interests of the organization from eminent risks posed by the macro environment and therefore, ought not to exist outside the sustainable adoption and effective implementation of Enterprise risk management strategy to ensure the achievement of set organizational goals. The linkage between Enterprise risk management and Top management demographics is therefore essential.

\section{Enterprise Risk Management, Macro Environment, Top Management Demographics, and Organizational Performance}

The fourth objective was to establish whether the difference between the Joint Effect of Enterprise Risk Management, Top Management Demographics and Macro Environment on the Performance in Kenyan State Owned Corporations, and whether this was different from their individual effect. To achieve this objective, this study set a corresponding hypothesis, H4: The joint effect of ERM, TMD and ME on the performance in Kenyan State Owned Corporations is different from their individual effect.

The study established that Enterprise risk management, Top management demographics and Macro environment had a statistically significant joint effect on organizational performance which was greater than the individual effects of enterprise risk management, top management demographics and macro environment on organizational performance. The joint effect was higher than and significant giving an $\mathrm{R} 2=0.208, \mathrm{~F}=3.406$ and $\mathrm{P}$-Value $=0.027<0.05$, as compared to the individual effect of ERM on organizational performance which gave R2 $=0.065$. The results confirmed that the joint effect of enterprise risk management, top management demographics and macro environment when regressed on organizational performance was greater than the individual effect of ERM when regressed on organizational performance. The hypothesis that the relationship between ERM and performance in Kenyan State-Owned Corporations is significantly moderated by the joint effect of TMD and ME, which is different from the individual effect was supported.

These findings revealed that organizational performance is an outcome of relationships arising from several different factors. Enterprise risk management, macro environment, top management demographics jointly exhibited higher organizational performance. The results are consistent with the findings of Murgor (2014) that established the importance of external environment on performance, Culp (1972) on the importance of macro environment in setting context to evaluate the importance of varying relationships on performance and Belanes and Hachana (2009) that managerial risk-taking is critical for higher organizational performance. 
The findings are also in tandemn with the findings by Mwangi (2018) that Top management teams has a significant effect on financial and non-financial performance, Mkalama (2014) that the combined effect of the Top management demographics has a statistically significant influence on performance and Culp (2002), that top management upon considerations of the various macro environmental forces supports enterprise risk management to influence organizational performance. Finally, this position is in line with the postulation of Aaker and Jacobson (1987) who established that an effective enterprise risk management strategy is a product of the full involvement of top management team in its formulation, upon adequately scanning the macro environment to inform the risk management strategy with a view to minimizing risks and maximizing on opportunities in order to enhance organizational performance.

Overall, the study reported mixed results with hypotheses 1, 3 and 4 exhibiting statistical significance whereas hypothesis 2 showed statistically not significant results. The results could stand on their own merit because of the evident recent introduction and gradual adoption of enterprise risk management as a strategic management practice in Kenyan state-owned corporations, not many studies have tested the effects of top management and macro environment on the enterprise risk management-performance relationship.

\section{Conclusion}

This study set out to establish the influence of Enterprise risk management, macro environment and Top management demographics and the performance of Kenyan state-owned corporations. Four specific objectives and hypotheses were laid out to achieve the main objective of the study. The hypotheses were tested before conclusions were made arising from the findings.

The study showed that Enterprise risk management had a significant influence on organizational performance. Kaplan and Mike (2014) posited that matching strategic risk management and contingent factors of a firm results in achieving desired outcomes. They advanced that effective management of organization-wide risks depends on organizational specific circumstances and context in which the organization operates and effective consideration of these factors and effective matching of this to enterprise risk management influences organizational performance. In line with this they proposed the Contingency theory of Enterprise risk management. This study concluded that Enterprise risk management significantly influenced organizational performance thus supporting the Contingency theory of Enterprise risk management.

The study further established that Macro environment did not significantly influence the relationship between Enterprise risk management and organizational performance. In outlining the Open Systems theory, Ansoff and McDonell (1990) postulated that organizations are environment serving and dependent. That environment consists of forces that are political, economic, sociological and technological in nature which firms do not have control over. This study tested this proposition and concluded that Macro environment did not influence the relationship between ERM and performance of Kenyan state-owned corporations. The statistically not significant results could be attributed to the positioning of Enterprise risk management in the public service as a fairly recent strategic management practice, coupled with the operating model of state corporation where focus is on the fulfillment of a constitutional or prescribed mandate thus assurances of ex-chequer funding as opposed to focus on profitability or bottom-line. This finding notwithstanding, organizations cannot overlook the established effect of Macro environment.

The study further revealed that Top management demographics did significantly influence the relationship between Enterprise risk management and organizational performance. Hambrick and Mason (1984) in advancing the Upper echelons theory posited that characteristics of senior managers affected the givens they brought to organizational decision situation when dealing with strategic decisions thus influencing performance. The findings of this study concluded that Top management demographics significantly influence the relationship between Enterprise risk management and organizational performance, thus supporting the Upper echelons proposition.

The study concluded that the joint effect of Enterprise risk management, Macro environment, Top management demographics on the performance of Kenyan owned state corporations was more significant as opposed to the individual effects of Enterprise risk management, Macro environment and Top management demographics. This is aligned to the proposition of Stakeholders theory (Freeman, 1984) which advances that performance is a function interconnectedness of strategies of various internal and external stakeholders in organizational decision-making process to enhance the effectiveness and outcomes of an organization.

Finally, the study's conceptual model was tested and retained as is by empirical evidence hence pointing to the likelihood of performance being influenced by more than one variable. The findings served to validate the main objective of this study by confirming that Enterprise risk management, Macro environment and Top management demographics jointly influence the performance of Kenyan owned state corporations. 


\section{References}

Aaker, D., \& Jacobson, R. (1987). The role of risk in explaining difference in profitability. Academy of Management Journal, 30(2): 227-296.

Abdel-Azim, M.H., \& Abdelmoniem, Z. (2015). Risk Management and Disclosure and their impact on firm value: The case of Egypt. International Journal of Business, Accounting and Finance, 9(1).

Ansoff, H.I., \& McDonnell, E.J. (1990). Implanting Strategic Management(2nd ed.). NY: Prentice Hall.

Arnaboldi, M., \&Lapsley, I. (2014). Enterprise-Wide risk management and organizational fit: A Comparative Study Journal of Organizational Effectiveness: People and Performance, 1(4): 365-377.

Baron, R. M. \& Kenny, D. A. (1986). The Moderator-Mediator Variable Distinction in Social Psychological Research: Conceptual, Strategic and Statistical Considerations. Journal of Personality and Social Psychology, 51, 11731182 .

Beasley, M., Chen, A., Nunez, K., \& Wright, L. (2006). Working hand in hand: balanced scorecards and ERM. Strategic Finance, 89(9): 49-56.

Belanes, A., \&Hachana, R. (2009). An operationalization of managerial risk-taking and its performance implication in the Tunisian context. Journal of Emerging Market Finance, 8(4): 289-314.

Burnes, B. (2004). Managing Change: A Strategic approach to firm's dynamics. $4^{\text {th }}$ Edition London: Prentice Hall.

Carpenter, M.A., Geletkanycz, M.A., \& Sanders, W.G. (2004). Upper echelons research revisited: antecedents, elements and consequences of top management team composition. Journal of Management, 30(6): 749-778.

Child, J. (1972). Organizational structure, environment, and performance: the role of strategic choice. Sociology, 6 (1), $1-22$.

Culp, C. (2002). The revolution in corporate risk management: a decade of innovations in process and product. Journal of Applied Corporate Finance, 14 (4): 8-26.

Freeman, R.E. (1984). Strategic Management: A stakeholder approach, Boston, MA: Pitman.

Gilley, K.M., Walters, B.A., \&Olso, B.J. (2002). Top management risk taking propensities and firm performance: Direct and moderating effects. Journal of Business Strategies. 19(2): 95-114.

Government of Kenya (2009).National Treasury Circular No.3/2009. Government Press.

Government of Kenya (2013).Report of the presidential taskforce on parastatal reforms. Retrieved at www.apsea.or.ke/.../76-report-of-presidential-taskforce-on-parastatal-reforms

Hambrick, D.C. \& Mason, P.A. (1984). "Upper Echelons": The organization as a reflection of its top managers'. Academy of Management Review.9: 195-206.

Hammond, J.S., Keeney, R.L., \& Raiffa, H. (2006). The hidden traps in decision making. Harvard Business Review, 84(1): 118-126.

Henderson, A. D., Miller, D., \& Hambrick, D. C. (2006). How quickly do CEOs become obsolete? Industry dynamism, CEO tenure, and company performance. Strategic Management Journal, 27(5): 447-460

Kaplan, S.K., \& Mikes A. (2014). Towards a contingency theory of enterprise risk management. Harvard Business School.

Kaplan, R. S., \& Norton, D.P. (1996). The Balanced Scorecard: Translating Strategy into Action, Boston, HBS Press.

Kim, L., \& Lim, Y. (1988). Environment, generic strategies, and performance in a rapidly developing country: A taxonomic approach. The Academy of Management Journal, 31(4): 802-827.

Kinuu, D. (2014). Top management team psychological characteristics, institutional environment, team processes and performance of companies listed on the Nairobi securities exchange. Unpublished PhD thesis, University of Nairobi.

Machuki, V.N., \&Aosa, E. (2011). The influence of external environment on the performance of publicly quoted companies in Kenya.Business Administration and Management Journal, 1(7), 205-218.

Marimuthu, M., \&Kolandaisamy, I. (2009). Can demographics diversity in top management team contribute for greater financial performance? An empirical discussion.The Journal of International Social Research, (2), 274-286.

McShane, M.K., Nair, A., \&Rustambekov, E. (2011). Does enterprise risk management increase firm value.Journal of Accounting, Auditing \& Finance, 26(4), 641-658.

McWhorter, L.B., Matherly, M., \&Frizzell, D.M. (2006).The connection between performance measurement and risk management.Strategic Finance, 87(7): 50-56.

Miller, C.C., Linda, M.B., \& William, H.G. (1998). Cognitive diversity among upper-echelon executive: implications for strategic decision processes. Academy of Management Journal, 19, 39-58.

Mkalama, R.N. (2014). Top management demographics, strategic decision making, macro-environment and performance of Kenyan state corporations. (Unpublished doctoral dissertation), University of Nairobi. 
Murgor, P.K. (2014). External environment, firm capabilities, strategic responses and performance of large scale manufacturing firms in Kenya.(Unpublished PhD Thesis).School of Business University of Nairobi.

Mwangi, P.G. (2018). Top management team heterogeneity and performance of large food and beverage manufacturing firms in Kenya. (Unpublished doctoral dissertation), University of Nairobi.

Njoroge, J., Gakure, R., Waititu, A., \&Katuse, P. (2013). Effects of strategic risk management on the growth of microfinance sector in Kenya. Prime Journals of Social Science, 2(7), 402-406.

Njoroge, J.K (2015). Strategy implementation, performance contracting, external environment and performance of Kenya state corporations. (Unpublished PhD Thesis).School of Business University of Nairobi.

Pearce, J. A., \& Robinson, R.B. (2003). Strategic Management: Formulation, Implementation and Control(8th ed.). New York: McGraw-Hill/Irwin.

Pfennigstorg, W. (1977). Governmental risk management in public policy and legislation: problems and options. Wiley, American Bar Foundation, 2(2):255-317.

Price Water House Coopers (PWC), (2015).Enterprise Risk Management in Public Sector. USA: PWC Publication.

Price Water House Coopers (PWC), (2012).Rising to the Next Flow. A Kenya perspective on 2012 state of the Internal Audit Profession Study. Nairobi: PWC Publication.

Radner, R., \&Shepp, L., (1996), Risk vs. profit potential: A model for corporate strategy. Journal of Economic Dynamics \& Control, 20(8):1373-1393.

Rao, A. (2007). Evaluation of enterprise risk management (ERM) in Dubai: An emerging economy. Risk Management, 9(3):167-187.

Ravitch, S.M., \&Riggan, M. (2012). Reason \& rigor: how conceptual frameworks guide research. Thousand Oaks: Sage Publications.

Schendel, D., \& Hofer, C.W. (1979). Strategic Management: A New View of Business Policy and Planning. Boston, Little Brown and Co.

Verlag, R.H. (2014). Risk management practices from risk maturity models perspective. Journal of East European Management Studies, 19(2):133-159.

Wernerfelt, B. (1984). A Resource Based View of the Firm. Strategic Management Journal 5(2), 171-180.

Wiersema, M.F., \&Bantel, K.A. (1992). Top management team demography and corporate strategic change.The Academy of Management Journal. 35(1):91-121.

Yamane, Taro. (1967). Statistics, An Introductory Analysis, 2nd Ed., New York: Harper and Row.

Yegon, C.K. (2015). Effect of Enterprise Risk Management Determinants on Financial Performance of Listed Firms in Kenya. (Unpublished Doctoral Thesis), Jomo Kenyatta University of Agriculture and Technology.

Zenger, T.D., \& Lawrence, B.S. (1989). Organizational demography: The differential effect of age and tenure distributions on technical communication. Academy of Management Journal, 23(2): 355-376.

Zikmund, W. G., Babin, B. J., Carr, J. C., \& Griffin, M. (2013).Business research methods.Cengage Learning. 